\title{
Teacher Non-Verbal Behavior as Part of Multimodal Interaction to Children with Autism
}

\author{
Djatmika \\ Universitas Sebelas Maret \\ Surakarta Indonesia \\ djatmika@staff.uns.ac.id
}

\author{
Agus Hari Wibowo \\ Universitas Sebelas Maret \\ Surakarta Indonesia \\ agushari67@staff.uns.ac.id;
}

\author{
Sugini \\ Universitas Sebelas Maret \\ Surakarta Indonesia \\ sugini@fkip.uns.id
}

\begin{abstract}
The paper discusses non verbal behavior performed and exploited by a teacher of children with autism as part of multimodal interaction in transferring knowledge. Data were collected from one teaching session carried out by a teacher and five children with autism. Data in the forms of body language, facial gesture, proximity, kinesics and other aspects of non verbal behavior were collected from such a session. The results show that strategies in exploiting non verbal aspects of the interaction are influenced by the autistic conditions of the children. As each of students in the class has different conditions, the teacher should design different non verbal approaches in transferring the knowledge to the children. In general, the teacher always equipped her utterances with body movements, facial gestures, standing position as well as paralinguistic resources such as intonation and loudness of speech. The strategies are performed to support the verbal behavior the teacher has in the teaching session and both represent multimodal interaction in the session. It is expected that the results of this research can be good benefits for other teachers or parents of children with autism in the process of assisting the children.
\end{abstract}

Keywords—autism, verbal, non verbal, behavior, multimodal

\section{INTRODUCTION}

Teaching children with autism needs special strategies related to verbal and non verbal aspects. To support these aspects, selecting and exploiting teaching aids is very important. Effective exploitation of such aspects plays an important role in making the teaching process go smoothly. This is due to the fact that the aim of the process is to increase the knowledge and skill of children with autism. Wenar suggested that such children have problems in communication. They generally have incapability in using language with other people (Safaria, 2005; Dover, \& Le Couteur, 2007; Blenner, Reddy, \& Augustyn, 2011) with several characteristics such as imitating interlocutors' utterances and action, wrongly selecting pronouns, and also having problem at reciprocal interaction.
The article is research-based discussing the quality of non verbal behavior teachers of autism center exploit in their teaching sessions for children with autism. A multimodal analysis was conducted to classify types of non verbal behavior in the form of body movement, proximity, facial gestures, or standing position and paralinguistic quality in the form of loudness and intonation. These aspects are related to the condition of the children. Pamuji (2007) stated that such children suffer a disfunction of brain development so that they are indicated to have problems in making communication and in making sosial interaction with other people. In addition, these children tend to show slow academic development. Helping children with autism to increase their capability to interact with other people is very challenging, because in common they are not aware and do not understand with is being communicated (Schuler and Fletcher, 2003; Sugini, Djatmika, \& Maryadi, 2016).

The problem in assisting the children to communicate using language can be associated with combining the spoken production and the auditorial process. Generally, they do not respond to utterances delivered by other people. If they might give responses, they are executed in a inconsistent pattern. Furthermore, initiating an exchange and maintaining the topic of a conversation are also problematic for them (Shulman, 2003). Ratey (as reported by Fletcher \& Schuler, 2003) claimed that this is the biological condition which influences the process of communication between children with autism and normal children. Based on the phenomenon, teachers for children with autism should consider strategies which are effective to accommodate the teaching process.

\section{Methodology}

This is a case study conducted on a teaching process performed by a female teacher to five children with autism. They are classified as autistic children with verbal capability. Data in the forms of facial gestures, body movement, standing point for proximity as well as paralinguistic aspects were 
collected from the session. They were then analysed to see how they were exploited mulitmodally in executing the class.

\section{RESULTS}

The observed class consists of four boys and one girl sufferring autism. They are all classified as children with verbal capability. However, in the teaching process only one child who showed good quality in using verbal aspects to communicate with the teacher-so that he can be categorized as a child with active verbal capability. He could catch the messages delivered in various utterances and could verbally respond to such utterances in an effective way. Furthermore, he could recite prayers and could read aloud a short text given by the teacher. In short, with his verbal capability, he showed effective responses to any verbal initiation performed by his teacher.The strategy of introducing reading skill for the children was taken by the teacher to stimulate them with skill of spelling letters to certain meaningful language units. This is different from what Fleury, Miramontez, \& Hudson (2014) have conducted. They investigated how reading aloud to children with autism might stimulate them with language units.

Meanwhile, the verbal responses performed by the rest of the children are very limited. They could only imitate what language units the teacher executed as models. They also had limited response to questions or instructions, even two of them tended to interact non verbally. In comparison to the active children, the remaining four children might be classified as children with passive verbal capability. The following table shows the condition of the children.

TABLE I. VERBAL CAPABILITY OF CHILDREN WITH AUTISM

\begin{tabular}{|c|c|c|c|}
\hline \multirow[t]{2}{*}{ Name } & \multicolumn{2}{|c|}{ Verbal Capability } & \multirow[t]{2}{*}{ Verbal Activities } \\
\hline & Active & Passive & \\
\hline Andrian & & $\sqrt{ }$ & $\begin{array}{l}\text { - imitating the pronunciation of the word baik } \\
\text { - fine" } \\
\text { imitating the pronunciation of the word } \\
\text { papah "father" } \\
\text { - responding a name call with the word of apa } \\
\text { a response meaning Yes Miss }\end{array}$ \\
\hline Fahri & & $\sqrt{ }$ & $\begin{array}{l}\text { - imitating the pronunciation of the word baik } \\
\text { - fine" } \\
\text { imitating the pronunciation of the word ayah } \\
\text { "father" } \\
\text { - responding a name call with the word of saya } \\
\text { a response meaning } I \mathrm{am}\end{array}$ \\
\hline Jose & & $\sqrt{ }$ & $\begin{array}{l}\text { - imitating the pronunciation of the word baik } \\
\text { "fine" } \\
\text { - responding a call with the word of apa a } \\
\text { response meaning Yes Miss }\end{array}$ \\
\hline Lucky & $\sqrt{ }$ & & $\begin{array}{l}\text { - imitating the pronunciation of the word baik } \\
\text { " fine" } \\
\text { imitating the pronunciation of the word ayah } \\
\text { "father" } \\
\text { - responding a call with the word of apa a } \\
\text { response meaning Yes Miss } \\
\text { - reading a short text } \\
\text { - reciting a prayer }\end{array}$ \\
\hline Vanessa & & $\sqrt{ }$ & $\begin{array}{l}\text { - imitating the pronunciation of the word baik } \\
\text { "fine" }\end{array}$ \\
\hline
\end{tabular}

The main materials to be introduced to the children are semantic units related to family and family members. The teacher developed several semantic units representing the main topic such as personal names, numbers, action as presented in the following table.

\section{TABLE II. SEMANTIC UNITS FOR THE TEACHING MATERIALS}

\begin{tabular}{|c|c|c|c|c|c|c|}
\hline Names of Day & $\begin{array}{l}\text { Name of } \\
\text { Month }\end{array}$ & $\begin{array}{c}\text { Personal } \\
\text { Name }\end{array}$ & $\begin{array}{l}\text { Addressing } \\
\text { Names }\end{array}$ & Numbers & Times & Activity \\
\hline "Senin "Monday" & Maret "March" & Andrian & ayah "father" & 18 & $\begin{array}{c}\text { kemarin } \\
\text { "yesterday" }\end{array}$ & $\begin{array}{c}\text { membaca } \\
\text { "read" }\end{array}$ \\
\hline \multirow[t]{6}{*}{ Minggu "Sunday" } & & Jose & papah "father" & 2018 & hari ini "today" & \\
\hline & & Lucky & ibu "mother" & & & \\
\hline & & Fahri & $\begin{array}{l}\text { mamah } \\
\text { "mother" }\end{array}$ & & & \\
\hline & & Vannesa & bunda" mother" & & & \\
\hline & & & $\begin{array}{l}\text { kakak "older } \\
\text { sibling" }\end{array}$ & & & \\
\hline & & & $\begin{array}{l}\text { adik "younger } \\
\text { sibling" }\end{array}$ & & & \\
\hline
\end{tabular}

The above table shows that the target of the class is introducing semantic units related to family and family members in the forms of words representing personal names and addressing names for family members such as ayah, papah, ibu, mamah, bunda, kakak, dan adik. In addition, several words were also given like an activity performed by family members on Minggu "Sunday", i.e. membaca "read"; name of the day the class was being performed, Senin "Monday"; and names of times related to these days, i.e. hari ini. "today" and kemarin "yesterday". Furthermore, from Seninthe teacher then told two numbers, i.e. delapan belas "eighteen" for the date of the day, and duaribu delapan belas "two thousand and twenty eight" for the year. She also mentioned Maret for the month of March.

In chronological order, the semantic units as the teaching materials were introduced by firstly mentioning the name of the day the teaching was undergoing with the date, the name of the month and the year to represent hari ini "today". Afterthat, the teacher asked the name of the prior daySunday-and what the children's family members did on that day. This question lead to membaca "to read" as the activity their family member did on Sunday. From this point, the teacher then went into the main materials of the teachingnames of family members and activity they usually do on certain day. A short text telling this material was then introduced and the children were stimulated to read it aloud befor the class. One student with the best verbal capability took the invitation and read such a text in front of other students. The following is the short text being introduced to the children.

Dito, ayah dan ibu gemar membaca "Dito, father, and mother like reading"

Dito membaca buku cerita "Dito reads story books" Ayah membaca koran "Father reads newspapers" Ibu membaca majalah "Mother reads magazines" Membaca membuat kita pandai "Reading makes us smart" 
The interesting thing related to the knowledge transfer of semantic units is that all of them were being introduced to the children both for their reading and writing skills. However, in the execution the teacher gave bigger portion for the reading than writing the semantic units. This is related to the condition of the class. Eventhough the children are in the class of verbal capability, only one student who has such an active capability, while the rest seem to have passive verbal capability. From such a condition, then the teacher did typical procedures for the introduction of the semantic units. She firstly introduced the units, then the children were asked to spell them or to say the unit. Afterthat, the units were written on the white board, and the students were asked to follow the teacher reading the units.

Unfortunately, the teacher in the teaching process inserted few units which are really related to the main topic of the teaching process. Furthermore, the units being introduced were considered to be too difficult for the chilren to understand as presented in the following table.

TABLE III. DIFFICULT SEMANTIC UNITS

\begin{tabular}{|l|l|l|}
\hline Activity & $\begin{array}{l}\text { Name of Education } \\
\text { Level }\end{array}$ & $\begin{array}{l}\text { Interrogative } \\
\text { Pronoun }\end{array}$ \\
\hline $\begin{array}{l}\text { upacara } \\
\text { "ceremony" }\end{array}$ & $\begin{array}{l}\text { SMA } \\
\text { "Senior High School" }\end{array}$ & $\begin{array}{l}\text { mengapa } \\
\text { "why" }\end{array}$ \\
\hline $\begin{array}{l}\text { ujian } \\
\text { "Examination" }\end{array}$ & & $\begin{array}{l}\text { dengan siapa } \\
\text { "with who" }\end{array}$ \\
\hline & & \\
\hline
\end{tabular}

The introduction of these difficult units was performed in the beginning of the class. When the teacher asked the name of the day the class of being conducted, she also asked why the children did not have a flag ceremony on that day represented in Mengapa pagi ini tidak upacara? "Why did you not have flag ceremony?" No student responded to such a question. This indicated that they were not capable to provide the answer for the question-in fact the answer which was presented by the teacher to such a question is Tadi pagi tidak upacara karena kakak kelas yang SMA sedang ujian. "We did not have a flag ceremony, because their senior students of Senior High School were having a final examination. In addition to the first difficult question, the teacher had another one asking "With who were you at home? This question actually sounds easier than the former, but only one student had a response to this represented in a word of teman "friend". He would like to say with a friend - an unexpected answer as the teacher actually wanted the children to tell with one of family members-so that she could then continue this with the main material, i.e. family and family members.

\section{A. Non Verbal Aspects in Teaching Process}

The teaching process was undertaken in a classroom with $2 \times 3 \mathrm{~m}^{2}$. Each student sat on a chair and a regulair table. They were arranged in a $U$ shape so that everybody could see the teacher. A whiteboard was position in the front of the class behind the stand point of the teacher. In conducting the class, the teacher in addition to her verbal exploitation also applied non verbal strategies. In general, the non verbal behavior the teacher did can be classified into two strategies, i.e. facial gestures and body movement. Furthermore,each strategy is in reality performed in several sub strategies as presented in the following table.

TABLE IV. NON VERBAL STRATEGIES

\begin{tabular}{|c|c|c|}
\hline Types & Activities & Functions \\
\hline \multirow[t]{4}{*}{ Facial Gestures } & smiling & to make the children feel relaxed \\
\hline & sticking out the tongue & $\begin{array}{l}\text { to stimulate the children in exploiting } \\
\text { organ of speech }\end{array}$ \\
\hline & mouth forming & $\begin{array}{l}\text { to provide models for producing } \\
\text { vowels }\end{array}$ \\
\hline & rounding the eyes & to attract the students' attention \\
\hline \multirow[t]{7}{*}{ Body Movement } & touching the chin & to attract the students' attention \\
\hline & setting the face toward the teacher & to attract the students' attention \\
\hline & hand rising & to provide a body movement model \\
\hline & $\begin{array}{l}\text { opening up the hand to pray in Islamic } \\
\text { way }\end{array}$ & to provide a model for praying \\
\hline & $\begin{array}{l}\text { rubbing the face with two hands in } \\
\text { saying amien to end an Islamic prayer }\end{array}$ & $\begin{array}{l}\text { to provide a model for ending an } \\
\text { Islamic prayer }\end{array}$ \\
\hline & $\begin{array}{l}\text { arranging the hands of the students in a } \\
\text { cross position }\end{array}$ & $\begin{array}{l}\text { to make the students concentrate on } \\
\text { the lesson }\end{array}$ \\
\hline & $\begin{array}{l}\text { showing family members' pictures } \\
\text { to students }\end{array}$ & $\begin{array}{l}\text { to introduce the physical } \\
\text { characteristics of family members }\end{array}$ \\
\hline
\end{tabular}

The above table presents two types of non verbal strategies performed by the teacher in the class of children with active and passive verbal capability. The first is related to face and parts of face exploitation such as eyes, lips, tongue, and mouth. These three parts are in reality exploited collaboratively. For example, in delivering a greeting utterance Apa kabar? to the students, the teacher provided a model for the response to such a greeting, i.e. baik "fine". A production model for this word was provided by the teacher by showing certain forms of the mouth to represent the production of the vowels [a] and [i]—so she showed the forms of mouth for low and open vowel and then followed by high and close one. Along with this process did the teacher open her eyes big and before giving the model, the teacher sticked out to invite the students producing the semantic units. These prosedures were executed to make the students relaxed.

Meanwhile, the teacher also performed body movements in her class. Each movement was undertaken for a certain purpose. Touching a student's chin was conducted to make her/ him give attention the teacher. This action was furthermore supported by directing her/ his gaze toward the teacher who was providing a model of saying certain words. For example, when a student did not respond to a greeting given the teacher, then she approached her/ him, touched her/ his chin, and directed her/ his gaze toward her so that the student could see her producing the semantinc unit being introduced. In this case, the action of touchin the chin and directing the gaze can represent a verbal expression of 
Attention please, or Look at Ms. Erni-or put in other words, if the non verbal action is verbalized such an action directed the students to give their attention to the teacher to observe how a semantic unit is being produced. In addition, eventhough the teacher verbally did not state explicitely, the mouth formation she perfomed might represent a verbal instruction for the student to copy her. To support such an implicit instruction, she positioned her face right in front of a child who personally became the target of the practice. Furthermore, she also supported the production model provision by exploiting facial gestures to accommodate the saying of semantic units related to family members.

The other non verbal action conducted by the teaching was to arrange a student's hand in cross position. Such a position represents that the student is ready to follow the teaching. Related to this non verbal meaning, everytime a student started not to be attentive or s/he did not concentrate to the teacher or to the teaching process, the teacher immediately did this action. Before arranging the hand in a cross position, she usually gave a model of such a position to the children. Other models were also presented for other body movements, such as hand rising, opening up the palm for an Islamic prayer position, rubbing the palm in ending an Islamic prayer, and hand clapping. The first was given by the teacher when she expected a response from the student to a name call performed by the teacher. They were expected to say saya "I am" by rising her/his hand. Meanwhile, the second and the third actions were performed in a sequence-after giving the model for praying in an Islamic way, she then followed it with the action model for ending such a prayer in an Islamic way, i.e. rubbing the palm on face while saying Amien. The last action, hand clapping, was introduced when they students were asked to sing a song together.

In the teaching process, the main materials were given along with an action of showing photograps of family members to each student one by one. The teacher showed one picture of a family member to a student. She positioned the picture just in front of the face of such a student so that $\mathrm{s} / \mathrm{he}$ could look and learn the physical characteristics of the family member while the teacher stated the name, like ayah "father", papah "father", $i b u$ "mother", and so on. The following step of this action was writing the word representing the family member and the students were then asked to read it aloud.

To support the exploitation of body movement, the teacher also arranged proximity - distance of standpoint between her and her students. Each non verbal action was performed with different proximity. There are three qualities for the proximity i.e. very close, close, and distant to accommodate the performance of non verbal action as presented in the following table.

\section{TABLE V. TEACHER PROXIMITY TO STUDENTS}

\begin{tabular}{|l|l|}
\hline Proximity & Activities \\
\hline Very Close & $\begin{array}{l}\text { showing a photo or a book } \\
\text { touching the chin } \\
\text { directing the students' gaze toward the } \\
\text { teacher's face } \\
\text { giving model for saying words }\end{array}$ \\
\hline Close & $\begin{array}{l}\text { explaining } \\
\text { asking } \\
\text { mentioning the students' names } \\
\text { helping the students accomplishing an } \\
\text { instruction } \\
\text { menjelaskan }\end{array}$ \\
\hline Distant & $\begin{array}{l}\text { writing words on the white board } \\
\text { spelling words } \\
\text { showing picture on the white board }\end{array}$ \\
\hline
\end{tabular}

There are three qualities of proximity performed by the teacher in the class presented in the table above. To distribute attention to all students, she had a standpoint in front of the class in a distant position. Sometimes, the teacher had a close position to a student who needed a special stimulation for an intiating utterance given by the teacher such as greeting, asking, instructing, and so on. The effective distance for executing these utterances was then modified even closer when the teacher personally provided models for saying words to certain students. Simply, these qualities were selected and executed by the teacher to support any non verbal action she conducted in the class. Put in other words, each non verbal action performed by the teacher needs an effective proximity to do. For example, a very close distance was taken when she touched a student's chain as well as directed her/ his gaze in getting her/his attention; or when she gave models for saying words; or when she showed a picture or a book to a student. In addition, a close ditance was selected for several verbal acts such as explaining, asking, and mentioning the children's names, whereas a distant proximity was taken when she wrote words on the whiteboard and spelled them, as well as showed pictures post on the board.

\section{CLOSING REMARKS}

There are four aspects discussed in this article, i.e. teaching materials, students' verbal capability, non verbal behavior and the teacher's proximity to the students. Each aspect is related to each other to simultantly become the parts of a teaching process discourse. The students's verbal capability is the main part the teacher based her decision to select and develop the teaching materials. Furthermore, the choice of teaching materials was then presented by exploiting verbal (but not to be discussed in this article), and non verbal strategies which were executed by selecting distance qualities. This is in line with what Emerson \& Dearden (2013) have claimed that the use of full language and stimuli including 
written words to engage children leads to a better understanding of complex language and literacy skills performed by children with autism. In addition, the effective non verbal exploitation will be more comprehensively performed and elaborated if they are related to the teaching aids used by the teacher in the teaching process.

\section{References}

Blenner, S., Reddy, A., \& Augustyn, M. (2011). Diagnosis and management of autism in childhood. British Medical Journal, 343 1-8

Dover, C.J., \& Le Couteur, A. (2007). How to diagnose autism. Autism, 92(6) 540-545

Emerson, A. \& Dearden, J. (2013). The effect of using 'full' language when working with a child with autism: Adopting the 'least dangerous assumption'. Child Language Teaching and Therapy, 29(2) 233-244

Fletcher, E. C. \& Schuler, A.L. (2003). Making communication meaningful (Cracking the language interaction code) In Gabriels, Robin,L \& Hill, Dina, E (eds.). Autism-from research to individualized practice. London: Jessica Kingsley Publishers.
Fleury, V.P., Miramontez, S.H. \& Hudson, R. F. (2014). Promoting active participation in book reading for preschoolers with Autism Spectrum Disorder: A preliminary study. Child Language Teaching and Therapy, 30 (3) 273-288

Pamuji. (2007). Model terapi terpadu bagi anak autisme. Jakarta: Departemen Pendidikan Nasional Direktorat Jenderal Pendidikan Tinggi Direktorat Ketenagaan

Safaria, T. (2005). Autisme: pemahaman baru untuk hidup bermakna bagi orang tua. Yogyakarta: Graha Ilmu.

Schuler, A.L. \& Fletcher, E.C. (2003). Making communication meaningful: cracking the language interaction code. In Autism-from research to individualized practice. Gabriels, Robin,L and Hill, Dina, E (eds.). London: Jessica Kingsley Publishers.

Shulman, C. (2003). Bridging the process between diagnosis and treatment. In Autism-from research to individualized practice. Gabriels, Robin,L and Hill, Dina, E (eds.). London: Jessica Kingsley Publishers.

Sugini, Djatmika, \& Maryadi (2016). Politeness strategies performed by teachers to effectively assist children with autism in their learning process. Humaniora, 28(1) 28-36 